\title{
PENGARUH LIKUIDITAS DAN SOLVABILITAS TERHADAP PROFITABILITAS PADA PERUSAHAAN MAKANAN DAN MINUMAN YANG TERDAFTAR DI BURSA EFEK INDONESIA
}

\author{
Dia Permata Sari 1), Aminar Sutra Dewi ${ }^{2)}$ \\ ${ }^{1,2)}$ Prodi Manajemen, STIE"KBP" \\ Email: diapermatasari729@gmail.com \\ Email Pembimbing: aminarsutradewi@akbpstie.ac.id
}

\begin{abstract}
This study aims to determine there is influence of liquidity and solvency ratio on profitability. This type of research is quantitative research that is data in the form of numbers. Population in this study are all food and beverage companies listed on the Indonesia stock exchange amounted to 14 companies. The sampel in this study amounted to 12 food and beverage companies listed on the Indonesian Stock Exchange. The technique of data analysis that is used is multiple linear regression by using program Eviews. From the results of tests conducted show that : 1) liquidity has a positive and significant impact on profitability, which is shown by probability > 0,05 is 0,9744. 2) Solvency has a positive and significant effect on profitability, which is shown by probability $>0,05$ that is 0,5041. Where the $R^{2}$ ( $R$-Square) value is $1,36 \%$.
\end{abstract}

Keywords: Liquidity, Solvency, Profitability.

\section{PENDAHULUAN}

Likuiditas adalah rasio yang memperhatikan hubungan kas perusahaan dan aktiva lancar lainnya terhadap kewajiban lancarnya (Weston \& Brigham, 2010). Pengaruh Likuiditas terhadap profitabilitas yaitu apabila nilai likuiditas perusahaan yang terlalu tinggi berdampak kurang baik terhadap kemampuan perusahaan memperoleh laba karena adanya dana yang menganggur atau menunjukkan kelebihan modal kerja yang dibutuhkan, kelebihan ini akan menurunkan kesempatan untuk memperoleh laba atau keuntungan perusahaan dengan demikian, kemungkinan hubungan current ratio dengan ROA adalah negatif. Semakin tinggi current ratio maka semakin rendah tingkat ROA. Ini menunjukan bahwa ada hubungan negatif signifikan antara likuiditas (current ratio) terhadap profitabilitas.

Faktor lainnya yang dapat mempengaruhi profitabilitas perusahaan 
adalah rasio solvabilitas. Menurut Munawir (2002) solvabilitas adalah kemampuan perusahaan untuk memenuhi kewajiban keuanganya apabila perusahaan tersebut dilikuidasikan baik kewajiban jangka pendek maupun jangka panjang. Berdasarkan pecking order theory dari Stewart C.Myear(1984), Semakin besar rasio solvabilitas menunjukan bahwa semakin besar biaya yang harus di tanggung perusahaan untuk memenuhi kewajiban yang dimilikinya. Hal ini dapat menurunkan profitabilitas yang dimiliki oleh perusahaan. Jadi semakin tinggi solvabilitas perusahaan maka kemampuan perusahaan untuk menghasilkan laba semakin rendah. Jika perusahaan menggunakan lebih banyak hutang dibanding modal sendiri maka tingkat solvabilitas akan menurun karena beban bunga yang harus ditanggung juga meningkat. Hal ini akan berdampak terhadap menurunnya profitabilitas.

\section{LANDASAN TEORI \& HIPOTESIS}

\section{Rasio Likuiditas}

\subsection{Current Ratio (Rasio Lancar)}

Merupakan rasio yang digunakan untuk mengukur kemampuan perusahaan dalam membayar kewajiban jangka pendeknya dengan menggunakan aktiva lancar yang dimiliki. Current Ratio dapat dihitung dengan rumus :

\section{Current Ratio $=($ Aktiva Lancar $/$ Utang Lancar) $x 100 \%$}

\section{Rasio Solvabilitas atau Leverage}

\subsection{Debt To Assets Ratio (DAR)}

Rasio ini merupakan perbandingan antara hutang lancar dan hutang jangka panjang dan jumlah seluruh aktiva diketahui. Rasio ini dapat dihitung dengan rumus:

Debt To Assets Ratio $=($ Total Utang / Total Asset) x 100\%

\section{Rasio Profitabilitas}

\subsection{Return On Assets (ROA)}

Merupakan rasio yang digunakan untuk mengukur kemampuan perusahaan dalam menghasilkan laba dengan menggunakan total aktiva yang ada dan setelah biaya-biaya modal (biaya yang digunakan mendanai aktiva) dikeluarkan dari analisis. Rasio ini dapat dihitung dengan rumus yaitu :

ROA $=($ Laba Bersih / Total
Aktiva $) \times 100 \%$

\section{Hipotesis Penelitian}


H1: Rasio Likuiditas berpengaruh positif dan signifikan terhadap profitabilitas pada perusahaan Makanan dan Minuman yang terdaftar di Bursa Efek Indonesia.

H2: Rasio Solvabilitas berpengaruh negatif dan signifikan terhadap profitabilitas pada perusahaan Makanan dan Minuman yang terdaftar di Bursa Efek Indonesia.

\section{METODE PENELITIAN}

\subsection{Jenis Penelitian}

Jenis penelitian yang ada dalam penelitian ini adalah penelitian kuantitatif.

\subsection{Objek dan Subjek Penelitian}

Objek penelitian ini adalah perusahaan yang terdaftar di Bursa Efek Indonesia. Subjek pada penelitian ini adalah Perusahaan Makanan dan Minuman yang Terdaftar di Bursa Efek Indonesia.

\subsection{Populasi dan Sampel}

Populasi dalam penelitian ini berjumlah 14 perusahaan. Sampel pada penelitian ini berjumlah 12 perusahaan dipilih berdasarkan teknik pengumpulan sampel purposive sampling dengan kriteria-kriteria tertentu.

\subsection{Jenis dan Sumber Data}

Penelitian ini menggunakan jenis data sekunder karena data yang diperoleh adalah data dari berbagai sumber yang telah ada yang diakses melalui situs www.idx.co.id.

\subsection{Teknik Pengumpulan Data}

Teknik pengumpulan data yang dilakukan penulis menggunakan teknik dokumentasi dengan mengumpulkan data, bukti, dan keterangan.

\subsection{Defenisi Operasional Variabel}

\section{Likuiditas (XI)}

Rasio yang menunjukan kemampuan perusahaan dalam memenuhi kewajiban jangka pendeknya.

$$
\mathrm{CR}=\frac{\text { Aset Lancar }}{\text { Hutang Lancar }} \times 100 \%
$$

\section{Solvabilitas (X2)}

Rasio yang menunjukan kemampuan suatu perusahaan dalam membayar hutang nya baik jangka panjang maupun jangka pendek.

$$
\text { DAR }=\frac{\text { Total Hutang }}{\text { Total Aset }} \times 100 \%
$$

\section{Profitabilitas (Y)}

Merupakan rasio yang menunjukkan kemampuan perusahaan untuk menghasilkan laba di dalam perusahaan.

ROA $=$ Laba Bersih $\quad \mathrm{x} 100 \%$ 
Total Aktiva

\subsection{Teknik Analisis Data}

\subsubsection{Analisa Statistik Deskriptif}

Uji statistik deskriptif berkenaan dengan bagaimana data dapat digambarkan/dideskripsikan, baik secara numerik misalnya menghitung rata-rata, standar deviasi atau secara grafis dalam bentuk tabel atau grafik.

\subsubsection{Uji Stasioneritas}

Stasioner merupakan suatu kondisi data time series yang jika ratarata, varian dan covarian dari perubah tersebut seluruhnya tidak dipengaruhi oleh waktu (Junaidi, 2012). Metode pengujian stasioneritas dan akar unit yang akan digunakan disini adalah metode Augmented Dickey Fuller (ADF) dan Phillips Perron (PP).

Model persamaannya sebagai berikut:

$$
\Delta \mathrm{Yt}=\mathrm{a} 0+\gamma \mathrm{Yt}-1+\Sigma \beta \Delta \mathrm{Yt}-1+1+\text { et }
$$

Keterangan:

Y : variabel yang diamati

$\Delta \mathrm{Yt}: \mathrm{Yt}-\mathrm{Yt}-1$
$\mathrm{T}:$ Trend waktu

\subsubsection{Uji asumsi klasik}

\section{a. Uji Normalitas Data}

Uji normalitas adalah uji untuk melihat apakah distribusi data mengikuti pola distribusi normal atau tidak.

\section{b. Uji Multikolinearitas}

Uji Multikolinearitas yaitu uji hubungan sesama variabel bebas. Syarat tidak terjadi multikolinearitas adalah jika nilai korelasi antar variabel independen < 0,8 . Jika nilai korelasi $>0,8$ maka terjadi multikolinearitas. (Gujarati, 2003).

\section{c. Uji Heteroskedastisitas}

Pengujian heteroskedastisitas dilakukan cara dengan melihat white heteroskedastisity test, dimana nilai probability Obs*R-squared > 0,05 (alpha). Oleh karena nilai probability Obs*Rsquared >0,05 maka tidak terjadi heteroskedastisitas.

\section{d. Uji Autokorelasi}

Uji yang digunakan untuk mendeteksi adanya gejala otokorelasi adalah DurbinWatson Statistic Test. Jika DurbinWatsonnya antara -2 sampai 2 berarti tidak terjadi otokorelasi. (Gujarati, 2003).

\subsubsection{Uji Regresi Linear Berganda}


Analisis regresi linier berganda adalah hubungan secara linear antara dua atau lebih variabel independen dengan variabel dependen (Y). Persamaan regresi linear berganda sebagai berikut:

$$
Y=\alpha+\beta 1 \times 1+\beta 2 \times 2+e
$$

\subsection{Uji Hipotesis}

\subsubsection{Uji F (Simultan)}

Pengujian ini dilakukan untuk mengetahui apakah semua variabel bebas yang digunakan dalam model regresi secara bersama-sama berpengaruh terhadap variabel terikat dan tingkat kesalahan atau probabilitas yang diinginkan $\mathrm{P}=5 \%$ (Ghozali, 2010).

\subsubsection{Uji t (Parsial)}

Pengujian secara parsial, dilakukan uji-t untuk menguji pengaruh masing masing variabel bebas terhadap variabel terikat dan tingkat kesalahan atau probabilitas yang diinginkan $\mathrm{P}=5 \%$ (Ghozali, 2005).

\subsubsection{Uji $\mathbf{R}^{2}$}

Uji $\mathrm{R}^{2}$ digunakan untuk mengetahui hubungan antara Rasio Likuiditas dan Rasio solvabilitas Terhadap Rasio Profitabilitas. Koefisien determinasi berkisar dari nol sampai dengan satu ( $0 \leq$ $\mathrm{R} 2 \leq 1)$.

\section{HASIL PENELITIAN DAN \\ PEMBAHASAN}

\section{HASIL PENELITIAN}

\section{Statistik Deskriptif Variabel}

\section{Penelitian}

\section{Tabel 1}

Deskriptif Statistik Variabel

Penelitian

\begin{tabular}{|c|c|c|c|c|c|}
\hline $\mathrm{V}$ & $\mathrm{N}$ & Minimum & Maksimum & Mean & $\begin{array}{c}\text { Standar } \\
\text { Deviasi }\end{array}$ \\
\hline $\mathrm{CR}$ & 36 & 0.080000 & 4.710000 & 1.868056 & 1.022249 \\
\hline DAR & 36 & 0.220000 & 4.360000 & 1.030833 & 0.998354 \\
\hline ROA & 36 & 3.190000 & 65.72000 & 11.63667 & 12.25467 \\
\hline
\end{tabular}

Sumber: Data diolah, Lampiran 3

Pada Tabel 1.1 diatas menunjukkan bahwa jumlah data yang digunakan dalam penelitian ini sebanyak 36 sampel data yang diambil dari Laporan Tahunan Publikasi sektor Makanan dan Minuman yang tercatat di BEI periode 2013 hingga 2015.

Data rasio $\mathrm{CR}$ terendah (minimum) adalah 0,08000 persen dan yang tertinggi (maksimum) 4,710000 persen. Kemudian rata-rata CR sebesar 1,868056 persen. Sementara standar deviasi sebesar 1,022249 menunjukkan simpangan data 
yang relatif kecil, karena nilainya yang lebih kecil daripada nilai mean-nya yaitu sebesar 1,868056 .

Data rasio DAR terendah (minimum) adalah 0,220000 persen dan yang tertinggi (maksimum) 4,360000 persen. Kemudian rata-rata DAR sebesar 1,030833 persen. Sementara standar deviasi sebesar 0,998354 persen menunjukkan simpangan data yang relatif kecil, karena nilainya yang lebih kecil daripada nilai mean-nya.

Data rasio ROA mempunyai tingkat terendah (minimum) adalah 3,190000 persen dan paling tinggi (maksimum) sebanyak 65,72000 persen. Kemudian ratarata ROA sebesar 11,63667 persen. Sementara nilai standar deviasi sebesar 12,25467 persen menunjukkan simpangan data yang relatif besar, karena nilainya yang lebih besar daripada nilai mean-nya.

\section{Uji Stasioneritas}

\section{Tabel 2}

\section{Hasil Uji Stasioneritas}

Sumber: Data diolah,Lampiran 2

Pada Tabel 2 di atas menunjukkan bahwa semua variabel baik independen maupun dependen telah stasioner dengan test for unit root in "level", dengan kata lain bahwa semua variabel telah stasioner pada test for unit root in tingkat awal atau tanpa perbaikan.

\section{Uji Asumsi Klasik}

\section{a. Uji Normalitas data}

Tabel 3

\section{Hasil Uji Normalitas Data}

\begin{tabular}{|l|c|c|c|c|}
\hline $\begin{array}{c}\text { Varia } \\
\text { bel }\end{array}$ & $\mathrm{N}$ & $\begin{array}{c}\text { Jarque- } \\
\text { Bera }\end{array}$ & $\begin{array}{c}\text { Probabili } \\
\text { ty }\end{array}$ & $\begin{array}{c}\text { Keterang } \\
\text { an }\end{array}$ \\
\hline CR & 36 & 5.587809 & 0.061182 & Nornal \\
\hline DAR & 36 & 5.446808 & 0.065651 & Normal \\
\hline ROA & 36 & 1.802491 & 0.406064 & Normal \\
\hline
\end{tabular}

Sumber: data diolah

Dari Tabel 3 di atas terlihat pada data probability untuk CR bernilai 0,061182 persen, probability untuk DAR bernilai 0,065651 persen, dan probability untuk ROA bernilai 0,406064 berarti data telah normal karena probability jargue-bera > 0,05 .

\section{b. Uji Multikolinearitas}

Tabel 4

\section{Hasil Uji Multikolinearitas}

\begin{tabular}{|c|c|c|c|}
\hline \multirow{2}{*}{ Variabel } & \multicolumn{3}{|c|}{ Tingkat Stasioneritas } \\
\cline { 2 - 4 } & \multicolumn{3}{|c|}{ Level } \\
\cline { 2 - 4 } & t-statistic & Probability & Keterangan \\
\hline $\mathrm{X} 1$ & $-2,3433$ & 0.1650 & Stasioneritas \\
\hline $\mathrm{X} 2$ & $-2,8990$ & 0.0562 & Stasioneritas \\
\hline $\mathrm{Y}$ & $-3,7447$ & 0.0075 & Stasioneritas \\
\hline
\end{tabular}




\begin{tabular}{|l|c|c|}
\hline & CR & DAR \\
\hline CR & 1.000000 & -0.058912 \\
\hline DAR & -0.058912 & 1.000000 \\
\hline
\end{tabular}

Sumber: Data Eviews

Berdasarkan hasil olahan data pada Tabel 4 terlihat nilai korelasi antara sesama variabel independen dibawah 0,8 sehingga dapat dikatakan bahwa sesama variabel independen tidak memiliki hubungan multikolinearitas.

\section{c. Uji Autokorelasi}

Tabel. 5

Hasil Uji Durbin -Watson

\begin{tabular}{|c|c|}
\hline Model & Durbin-watson \\
\hline 1 & 1.122472 \\
\hline
\end{tabular}

Sumber: Data diolah, Lampiran 6

Dari uji Durbin-watson pada Tabel 5

terlihat bahwa tidak terjadi Autokorelasi karena nilai Dw antara $-2<1.122472<2$.

\section{d. Uji Heteroskedastisitas}

Tabel 6

\section{Hasil Uji Heteroskedastisitas}

Sumber : Data diolah, Lampiran 5

Pada Tabel 6 terlihat tidak terjadi heteroskedastisitas karena nilai probability Obs*R-squared yaitu 0,1955>0,05. 
Tabel 7

Hasil Regresi Linear Berganda

\begin{tabular}{cclcr}
\hline \hline Variable & Coefficient & Std. Error & t-Statistic & Prob. \\
& & & & 0.0485 \\
X1 & 0.270375 & 0.131941 & 2.049208 & 0.9744 \\
X2 & 0.004601 & 0.142168 & 0.032361 & 0.5041 \\
& 0.084651 & 0.125329 & 0.675427 & \\
\hline \hline R-squared & & & & 0.094718 \\
Adjusted R-squared & -0.046142 & S.D. dependent var & -1.751055 \\
S.E. of regression & 0.096879 & Akaike info criterion & -1.619095 \\
Sum squared resid & 0.309722 & Schwarz criterion & -1.704997 \\
Log likelihood & 34.51899 & Hannan-Quinn criter. & 1.255978 \\
F-statistic & 0.228129 & Durbin-Watson stat & \\
Prob(F-statistic) & 0.797267 & &
\end{tabular}

Sumber : Data Eviews

Ini menunjukkan koefisien kolerasi

Dari tabel 7 diatas, dapat dituliskan likuiditas (X1) sebesar 0,004601. Jika persamaan sebagai berikut: variabel likuiditas meningkat $1 \%$ maka profitabilitas akan mengalami penurunan $\mathrm{Y}=0,270375+0,004601 \mathrm{X} 1+0,084651$ sebesar 0,004601 poin, dan sebaliknya $\mathrm{X} 2+\mathrm{e}$. apabila likuiditas menurun $1 \%$ maka profitabilitas akan mengalami peningkatan

Dimana nilai konstanta sebesar 0,270375. Nilai koefisien ini menunjukkan jika tidak ada perubahan pada variabel likuiditas dan solvabilitas maka profitabilitas akan mengalami penurunan sebesar 0,270375 poin. sebesar 0,004601 poin.

Koefisien kolerasi solvabilitas (X2) sebesar 0,084651. Jika variabel solvabilitas meningkat $1 \%$ maka profitabilitas akan mengalami penurunan sebesar 0,084651 
poin, dan sebaliknya apabila likuiditas menurun $1 \%$ maka profitabilitas akan mengalami peningkatan sebesar 0,084651 poin.

\section{Uji Hipotesis}

\section{a. Uji Koefisien Rergresi Secara Simultan (F)}

Dari Tabel 7 dihasilkan nilai $F$ Statistic sebesar 0.228129 dengan nilai signifikansi probability F-Statistic adalah 0.797267, tingkat probabilitasnya lebih besar dari 0,05 atau >0,05. Hal tersebut mengindikasikan bahwa semua variabel independen (CR dan DAR) berpengaruh secara signifikan terhadap variabel dependen (Profitabilitas).

\section{b. Uji Koefisien Regresi Secara Parsial (t)}

Dari tabel 7 di atas, dapat dituliskan persamaan sebagai berikut:

$\mathrm{ROA}=0.270375+0.004601 \mathrm{CR}+$ 0.084651 DAR. Nilai konstanta sebesar 0.270375 berarti bahwa nilai ROA adalah sebesar 0.270375 dengan asumsi variabel lain bernilai nol.

Jika dengan peningkatan $1 \% \quad \mathrm{CR}$ (Current Ratio), maka akan mengakibatkan peningkatan nilai koefisien ROA (Return on Asset) sebesar 0.0046\%. Dan apabila dengan peningkatan 1\% DAR (Debt to Assets Ratio), maka akan mengakibatkan peningkatan nilai koefisien ROA (Return on Asset) sebesar 0,0846\%.

\section{c. Uji Koefisien Determinan $\left(\mathbf{R}^{\mathbf{2}}\right)$}

Dari hasil pengolahan data ditemukan nilai $R$-squared 0,013637 ini berarti bahwa variabel bebas CR (Current Ratio) dan DAR (Debt To Assets Ratio) mempengaruhi ROA (Return On Asset) sebesar $1,36 \%$ sedangkan sisanya $98,6 \%$ dipengaruhi oleh faktor lain.

\section{PEMBAHASAN}

\section{Pengaruh Likuiditas terhadap Profitabilitas}

Dari Tabel 7 dihasilkan nilai koefisien regresi untuk variabel Likuiditas yaitu CR (Current Ratio) sebesar 0.004601 bertanda positif dengan nilai probabilita $0.9744>0,05$ yang berarti bahwa Current Ratio mempunyai pengaruh positif yang signifikan terhadap Profitabilitas yaitu ROA (Return On Assets). Dengan demikian dapat disimpulkan hipotesis pertama diterima.

\section{Pengaruh Solvabilitas terhadap Profitabilitas}

$\begin{array}{lll}\text { Dari } & \text { Tabel } 7 \text { dihasilkan nilai } \\ \text { koefisien } & \text { regresi untuk variabel } \\ \text { Solvabilitas } & \text { yaitu DAR (Debt to Assets } \\ \text { Ratio) sebesar } & 0.084651 \text { bertanda positif }\end{array}$

Dari Tabel 7 dihasilkan nilai koefisien regresi untuk variabel Ratio) sebesar 0.084651 bertanda positif 
dengan nilai probabilita $0.5041>0,05$ yang berarti bahwa solvabilitas mempunyai pengaruh positif yang signifikan terhadap Profitabilitas yaitu ROA (Return On Asset) - Dengan demikian dapat disimpulkan hipotesis kedua ditolak.

\section{KESIMPULAN}

1. Rasio Likuiditas yaitu Current Ratio mempunyai pengaruh positif yang signifikan terhadap profitabilitas yaitu Return on Asset yang ditunjukkan dengan nilai probabilitas lebih besar dari 0,05 yaitu sebesar 0,9744 .

2. Rasio Solvabilitas yaitu Debt to Assets Ratio mempunyai pengaruh positif yang signifikan terhadap profitabilitas yaitu Return on Asset yang ditunjukkan dengan nilai probabilitas lebih besar dari 0,05 yaitu sebesar 0,5041.

\section{SARAN}

1) Bagi peneliti selanjutnya, diharapkan melakukan penelitian lanjutan dengan memperluas sampel dan data penelitian. Misalnya dengan menggunakan periode pengamatan yang lebih panjang serta menambahkan variabel independen lain yang diduga mempengaruhi profitabilitas.

2) Bagi Peneliti selanjutnya untuk penelitian dengan topik yang sama terutama mengenai Profitabilitas yang menggunakan ROA, sebaiknya peneliti berikutnya menggunakan yang lain misalnya ROI, ROE, GPM, NPM.

3) Untuk penelitian selanjutnya sebaiknya menambahkan jumlah tahun sampelnya atau memperluas periode penelitian yang akan diteliti dan juga memakai program olah data yang berbeda dari penelitian sebelumnya.

4) Bagi peneliti selanjutnya juga diharapkan menggunakan sampel perusahaan manufaktur yang berbeda, sehingga hasil penelitian ini dapat diperbandingkan dan juga untuk melihat apakah pengaruh likuiditas, solvabilitas terhadap profitabilitas di sektor perusahaan yang berbeda.

\section{DAFTAR PUSTAKA}

Andriza, R., \& Yusra, I. (2019). Pengaruh kepemilikan manajerial dan kebijakan deviden terhadap kemakmuran Investor dan nilai perusahaan yang tercatat pada indeks LQ45. INA-Rxiv. 
Afrinda, Nidya. 2013. "Analisis Pengaruh Likuiditas dan Solvabilitas terhadap Profitabilitas Pada Perusahaan Manufaktur Sektor Makanan dan Minuman yang Terdaftar Di Bei Tahun 2006-2012. Manajemen Universitas Diponegoro. Semarang.

Baridwan, Zaki. 2004. Intermediate Accounting. BPFE. Yogyakarta.

Danil, A., \& Yusra, I. (2019). Pengaruh kausal antara ukuran perusahaan, nilai buku dan likuiditas saham di Bursa Efek Indonesia. INA-Rxiv.

Erawati, L., \& Dewi, A. S. (2019). Peran Profitabilitas Sebagai Variabel Interverning Dan Pengaruh Struktur Modal Terhadap Nilai Perusahaan. INA-Rxiv.

Fahmi, Irham. 2011. Analisis Laporan Keuangan. Bandung: Alfabeta.

Fajri, I., \& Dewi, A. S. (2019). Analisis Likuiditas, Profitabilitas, dan Return Saham pada Perusahaan Manufaktur di Indonesia. INA-Rxiv.

Gryglewicz, Sebastian. 2010. A theory of corporate financial decisions with liquidity and solvency concerns.

Hadya, R. (2013b). Pengaruh Harga dan Risiko Saham terhadap Likuiditas Saham Pada Perusahaan-Perusahaan Yang Terdaftar Di Bursa Efek Indonesia. Jurnal KBP, 1(2), 208-231. Retrieved from https://akbpstie.ac.id/cmsz/medias/file/ 9. rizka hadya.pdf

Hadya, R. (2014a). Analisis likuiditas, solvabilitas, nilai pasar dan return saham: studi empiris pada perusahaan sektor perbankan yang terdaftar di Bursa Efek Indonesia. Jurnal Riset
Manajemen Dan Akuntansi, 3(1), 107118.Horne, James C Van \& John M. Wachowicz, JR. 2009. Prinsip-prinsip Manajemen Keuangan. Jakarta: Salemba Empat.

Hanafi, D., \& Yusra, I. (2019). Tangibility, liquidity, growth opportunity, dan leverage: studi pada perusahaan terdaftar di Bursa Efek Indonesia. INARxiv, (2001).

Kasmir. 2013. Analisis Laporan Keuangan. Jakarta: PT. Raja Grafindo Persada.

Kurniawan, A., \& Yusra, I. (2019). Apakah profitabilitas dan nilai buku berdampak terhadap return saham?: studi empiris pada perusahaan LQ45. INA-Rxiv.

Manurung, Erma Risdo Tohonan, dkk. 2012. Pengaruh Likuiditas dan Solvabilitas Terhadap Profitabilitas pada Perusahaan Real Estate dan Property Bursa Efek Indonesia. Pekanbaru.

Mulfita, A., \& Yusra, I. (2019). Analisis regresi data panel terhadap likuiditas saham di Indonesia. INA-Rxiv.

Munawir, S. 2004. Analisis Rasio Keuangan. Yogyakarta: Penerbit Liberti.

Prastowo, Dwi. 2005. Analisis Laporan Keuangan Konsep dan Aplikasi. YPKN. Yogyakarta.

Putra, A. D., \& Yusra, I. (2019). Peran profitabilitas dalam memoderasi pengaruh free cash flow terhadap kebijakan dividen di Indonesia. INARxiv.

Putra, I., \& Yusra, I. (2019). Analisis likuiditas saham menggunakan regresi data panel. INA-Rxiv. 
Qusibah, V. L., \& Yusra, I. (2019). Profitabilitas, dan Ukuran Perusahaan Sebagai Faktor Penentu Leverage Perusahaan Di Indonesia. Jurnal Pundi, 03(01), 13-26. https://doi.org/10.31575/jp.v3i1.125

Riyanto, Bambang. 2004. Dasar-Dasar Pembelajaran Perusahaan. Edisi Ketiga. Yogyakarta: Penerbit Yayasan Badan Penerbit Gajah Mada.

Riyanto, Bambang. 2008. Dasar - dasar Pembelajaran Perusahaan. BPPE. Yogyakarta.

Sari, N. N., \& Yusra, I. (2018). Analisis Likuiditas, Leverage dan Kebijakan Dividen berdasarkan Siklus Hidup Perusahaan pada Saham LQ45. INARxiv.

Sunyoto, Danang. 2013. Analisis Laporan Keuangan untuk Bisnis. Yogyakarta : CAPS

Weston, J.Fred. \& Eugene F. Brigham, 2010. Dasar-dasar manajemen Keuangan. Jakarta: Erlangga.

Yusra, I., Hadya, R., \& Fatmasari, R. (2019). The Effect of Retained Earnings on Dividend Policy from the Perspective of Life Cycle. Advances in Social Science, Education and Humanities Research, 203(Iclick 2018), 216-220. 